\title{
Covid-19: Women's health campaigners sue FDA over access to medical abortion pills
}

\author{
Janice Hopkins Tanne
}

New York, USA

A group of prominent women's health organisations are suing the Food and Drug Administration (FDA) for preventing telemedicine prescribing of mifepristone, one of the drugs used in early abortions and miscarriages. It is the only prescription drug with such a restriction.

The plaintiffs argue that the prohibition on telemedicine prescribing and mail delivery of mifepristone puts both the patient and the provider at risk of exposure to covid-19 during the current pandemic. Public health authorities have urged people to stay home as much as possible and the Centers for Disease Control and Prevention advised people to fill prescriptions by mail.

Those behind the action are the American Civil Liberties Union (ACLU), the American College of Obstetricians and Gynecologists, the Council of University Chairs of Obstetrics and Gynaecology, Planned Parenthood of America, the New York State Academy of Family Physicians, and the Sister Song Women of Colour Reproductive Justice Collective.

The lawsuit asking for emergency relief was filed in the US District Court in Maryland. ${ }^{1}$ A representative of the ACLU told The BMJ that oral arguments in the case will likely be heard later this month.

Women on low incomes and women of colour, who make up $75 \%$ of those seeking abortion, will bear the brunt of FDA's restrictions. ${ }^{2}$ Arranging transportation and child care and travelling to pick up a pill is difficult for many in ordinary times. In a pandemic, travel and in person meetings mean they face an increased risk of covid-19 infection, and they expose the doctors and clinicians who dispense the drugs to increased risk of covid-19 as well.

In a statement, ACLU said, "Federal agencies have taken every opportunity to encourage telemedicine use and give clinicians the flexibility to forgo unnecessary in person encounters in accordance with their clinical judgment. They have waived various rules requiring in person visits, even for controlled substances like opioids.

"But there is one striking exception. The FDA requires that mifepristone be dispensed only in a hospital, clinic, or medical office," even if the patient has been evaluated by a clinician by telemedicine or at an in person visit.

"Of the more than 20000 drugs regulated by the FDA, mifepristone is the only one that patients must obtain in a clinical setting, yet may self-administer unsupervised at home," the ACLU says. It also notes that when the drug is used for a purpose other than early abortion, FDA permits it to be sent to patients' homes in larger quantities and doses.

Mifepristone is extremely safe, the ACLU notes, quoting the FDA's own words that its "efficacy and safety have become well established by both research and experience, and serious complications have proven to be extremely rare. The drug has been FDA approved for 20 years and used by more than four million people.

Medical abortions - up to 10 weeks after the last menstrual period-have increased since the regimen was approved in 2000 and now account for more than one third of all abortions (39\%) in the US. ${ }^{3}$ The same drugs are also used in the treatment of miscarriage, to make sure the miscarriage is complete. The regimen includes a consultation between patient and provider, an oral dose of mifepristone followed 24 to 48 hours later by an oral dose of misoprostol. While the FDA currently requires the patient pick up mifepristone in person, misoprostol can be prescribed by telemedicine and delivered by mail.

American College of Obstetricians and Gynecologists. Council of University Chairs of Obstetrics and Gynecology; New York State Academy of Family Physicians; SisterSong Women of Color Reproductive Justice Collective; and Honor MacNaughton, MD, $v$ United States Food and Drug Administration; Stephen M. Hahn, MD, in his official capacity as Commissioner of Food and Drugs; United States Department of Health and Human Services; and Alex Azar, JD, in his official capacity as Secretary, United States Department of Health and Human Services. 27 May 2020. www.courthousenews.com/wp-content/ uploads/2020/05/Abortion.pdf.

2 Guttmacher Institute. US abortion patients. 2016. www.guttmacher.org/infographic/2016/ us-abortion-patients.

3 Guttmacher Institute. Medication abortion. 12 November 2019. www.guttmacher.org/print/ evidence-you-can-use/medication-abortion.

This article is made freely available for use in accordance with BMJ's website terms and conditions for the duration of the covid-19 pandemic or until otherwise determined by BMJ. You may use, download and print the article for any lawful, non-commercial purpose (including text and data mining) provided that all copyright notices and trade marks are retained.

https://bmj.com/coronavirus/usage 